\title{
ICT IMPLEMENTATION IN THE KINDERGARTEN EDUCATION SYSTEM IN THE CZECH REPUBLIC
}

Ivana BE $\check{C} \boldsymbol{V} \boldsymbol{A} \breve{R} \boldsymbol{O} \boldsymbol{V} \boldsymbol{A}$, Filmová akademie Miroslava Ondříčka, Česká republika Lenka HRUŠKOVÁ, Metropolitní univerzita Praha, Česká republika Jana KRÁTK $\boldsymbol{A}^{*}$, Metropolitní univerzita Praha, Česká republika

Přijato: 30. 9. 2017 / Akceptováno: 4. 12. 2017

Typ článku: Výzkumná studie

DOI: $10.5507 /$ jtie.2017.031

Abstract: The study deals with the implementation of information and communication technologies in the educational environment of kindergartens within the emerging trend of joint education. It briefly analyzes the Framework Educational Program of pre-school education and its changes in the use of digital technologies. The study aims on the kindergarten teachers' view on the drawback and the positive benefits that ICT brings with them. It maps out and compares the digital equipment of individual kindergartens in the South Bohemia, Pilsen region and Prague, the level of the digital competences of the teachers of the kindergarten, including methodical facilities and opinion prejudices and attitudes towards ICT.

Key words: ICT, kindergarten, teacher, joint education (inclusion).

\section{IMPLEMENTACE ICT DO SYSTÉMU VZDĚLÁVÁNÍ V MATEŘSKÝCH ŠKOLÁCH V ČESKÉ REPUBLICE}

Abstrakt: Studie se zabývá problematikou implementace informačnich a komunikačnich technologii do edukačního prostředi mateřských škol v rámci nastupujicího trendu společného vzdělávání. Stručně analyzuje Rámcový vzdělávací program předškolního vzdělávání i jeho proměny z hlediska využivání digitálních technologií. Cílem je poznat úskali i pozitiva, která s sebou ICT přinášeji v pohledu učiteli̊ MŠ. Studie mapuje a porovnává digitální vybavení jednotlivých mateřských škol v Jihočeském kraji, Plzeňském kraji a v Praze, úroveň digitálnich kompetencí učitelů $M S ̌$, včetně metodické vybavenosti, jejich názorové předsudky i postoje kICT.

Klíčová slova: ICT, mateřská škola, učitel, společné vzdělávání (inkluze).

*Autor pro korespondenci: j.m.kratka@ seznam.cz 


\section{ICT v mateřských školách}

Implementace informačních a komunikačních technologií do výuky škol je předmětem mnohých polemik. Zastánci moderních technologií zdůrazňují, že technologická a digitální vybavenost škol je prvořadým úkolem ČR, nebot' věda, výzkum i běžný život je pod jejich vlivem. Také Strategie digitálního vzdělávání v ČR do roku 2020 jako státní koncepce podporuje smysluplné digitální vzdělávání, tj. jak se s technologiemi pracuje a jak se pohybovat v on-line prostředí (Strategie digitálního vzdělávání v ČR do roku 2020, 2017). Odpůrci mluví o „digitální demenci“, tj. o duševním zmrzačení dětí, které jsou díky ICT roztěkanější, žijí v mentálních bublinách sociálních médií, vedou pět konverzací najednou a méně se naučí (Spitzer, 2014). Německý neurolog Manfred Spitzer v mnohých výzkumech dokládá alarmující výsledky. Na digitálních médiích podle něj vzniká závislost, která v dlouhodobém horizontu poškozuje tělo i mysl. Jakmile člověk přestane vyvíjet duševní úsilí, ochabuje pamět'. U dětí a mladistvých vinou digitálních médií dramaticky klesá schopnost učení a výsledkem jsou poruchy pozornosti a čtení, úzkost a otupělost, poruchy spánku a deprese, nadváha, sklony k násilí a úpadek společnosti. Spitzer (2016) vybízí k omezení konzumního způsobu života. Trend waldorfských škol a lesních mateřských škol v ČR dává také větší důraz na kontakt $\mathrm{s}$ hmatatelným reálným světem, prrírodou a pohyb v ní. Jde spíše o to, jak zvládat digitální média tak, aby neškodila. Nedůvěra v pomoc digitálních technologií v českém školství ale přetrvává.

Vize implementace digitálních technologií do mateřské školy pomocí digitální hračky a počítače se stává realitou. Na základě průzkumu, který jsme ve vybraných lokalitách ČR udělali, jsme zjistili, že trh nabízí MŠ dostatečné množství kvalitních multifunkčních zařízení (scaner, kopírovací stroj, digitální fotoaparát či kameru) a multifunkčních aplikací (např. MultiBoard, 3BOX, dotykové tablety) a programovatelné hračky (Pixie, Bee-Bot), vč. různých softwarových prostředí. Mezi nejvíce oblíbené patří 3BOX ,který sestává z interaktivního koberce, interaktivního stolu, interaktivní stěny, které se dají různě kombinovat. MultiBoard je dotykový, jeho výhodou je multifunkčnost a variabilita. Má interaktivní displej na mobilním stojanu a integrovaný počítač s kvalitním výukovým obsahem a aplikacemi, umožňuje používat internet, přehrávat videa. Ovládá se propisovači nebo dotykem, je desetidotykový (tj. 10 dětí může simultánně pracovat). Předností je nízká hmotnost, vysoká mobilita umožňující využití ve třídě i mimo ni. Digitální pomůcky zůstávají však v ČR finančně nákladnou pomůckou a ne každá MŠ je může vlastnit. Mnoho učitelů vítá a implementuje ICT do výuky dle svého uvážení, experimentuje a rozvíjí badatelsky orientovanou výuku. Zamýšlí se nad otázkami, zda digitální technologie pomohou naplnit vzdělávací cíle, jaké IT lze použít při práci s dětmi, jakým způsobem, co získají děti při práci s takovými nástroji. Př́ičinou obav učitelů je mnohdy nedostatečná technická a digitální gramotnost a strach z nových technologií, jejich selhání atp. (O’Hara, 2004). Rozporuplnost této problematiky nás vedla k následujícímu výzkumu.

\section{Metodologie}

Výzkumné šetření bylo realizováno v roce 2016 v rámci projektu OP VVV „Mateřské školy jako centra kolegiální podpory v oblastech zaměřených na individualizaci vzdělávání a rozvoj kreativity“ CZ.02.3.68/0.0/0.0/16_010/0000511. V souladu s aktuálními př́stupy užívanými $\mathrm{v}$ oboru byly využity následující metody: Metoda kvantitativní (nestandardizované dotazníkové šetření), metoda kvalitativní (rozhovor s učiteli a řediteli mateřských škol, pomocnou metodou byla metoda pozorování). Výzkumné šetření bylo 
provedeno na dostupném vzorku vybraných škol ve třech sledovaných regionech prostřednictvím dotazníku (srov. Chráska, 2007), který obsahoval 10 otázek, tj. uzavřené položky s možností výběru, otevřené položky, které byly zařazeny za účelem zdůvodnění volby konkrétních odpovědí. Otázky byly směrovány k posouzení reálného vybavení didaktickou technikou (ICT) v jednotlivých mateřských školách a jejich využívání při edukaci, tj. jakými multimediálmími aplikacemi a multifunkčními zařízení disponuje, jak jsou využívána apod.). Mapovali jsme také digitální kompetence a postoje učitelů MŠ při implementaci ICT jako podpůrného prostředku společného vzdělávání. Metoda rozhovoru a pozorování s učiteli a řediteli mateřských škol měly doplňující význam s cílem zpřesnění získaných informací.

\section{Vymezení základních pojmů souvisejících s řešenou problematikou}

Termín ICT je zkratkou pocházející z anglického pojmu Information and Communication Technologies, v překladu informační a komunikační technologie, které zahrnují veškeré technologie používané pro komunikaci a práci s informacemi (Institut pro veřejnou správu Praha, 2012). ICT lze označit jako souhrn softwarových, hardwarových a komunikačních komponent (ISO/IEC/IEEE 24765, 2010). Multimédia jsou charakterizována jako oblast informačních a komunikačních technologií, která je charakteristická sloučením audiovizuálních technických prostředků s počítači či dalšími zařízeními. „Digitální gramotnost a digitální kompetence jsou vymezovány jako soubor vědomostí, dovedností, schopností, postojů a hodnot, které jedinec potřebuje, aby využil digitální technologie a digitální média k činnostem.“ (Strategie digitálního vzdělávání do roku 2020, 2014, str. 47-48). V České republice bylo v této oblasti realizováno mnoho výzkumných šetření a publikována řada teoretických studií, které se zaměřovaly na využívání ICT ve školách (Černochová et al., 2004; Brdička, 2003; Zounek, 2006). Také v zahraničí je problematice informačních a komunikačních technologií věnována velká pozornost, např. ICT and Quality of Learning (Venezky, Davis 2002).

„Rámcový vzdělávací program pro předškolní vzdělávání (RVP PV) vymezuje hlavní požadavky, podmínky a pravidla pro institucionální vzdělávání dětí předškolního věku“ (RVP PV, 2017, str. 5). Text upraveného Rámcového vzdělávacího programu pro předškolní vzdělávání, je platný od února 2017. Vychází z nové strategie vzdělávání, která zdůrazňuje klíčové kompetence a jejich provázanost se vzdělávacím obsahem, a také z Akčního plánu inkluzivního vzdělávání na období 2016-2018, který staví na rovném přistupu ke vzdělávání a individualizaci. RVP PV je kurikulární dokument, který je v určitých časových etapách inovován v závislosti na společenských změnách, zkušenostech učitelů a měnících se potřebách dětí (Bečvářová, 2016). „Stanovuje elementární vědomostní základ a společný rámec, ze kterého vycházejí Školní vzdělávací programy (ŠVP) v konkrétních mateřských školách a ostatních vzdělávacích zařízeních. Situační učení a spontánní sociální učení jsou využívány v integrovaných blocích, které nerozlišují vzdělávací oblasti. Vzdělávací obsah je dítěti nabízen v prrirozených souvislostech smysluplně a odráží životní realitu. Dítě nezískává izolované poznatky, ale způsobilost podloženou praktickou činností, tj. kompetence.“ (RVP, 2017, str. 11).

V prezentovaném výzkumu sledujeme digitální kompetence u učitelů MŠ ve smyslu jejich připravenosti pro práci s dětmi předškolního věku a osvojování těchto kompetencí. U dětí předškolního věku jsou digitální kompetence především součástí kompetencí komunikativních, tj. dítě dovede využít informativní a komunikativní prostředky, 
tj. knihy, encyklopedie, počítač, audiovizuální technika, telefon atd. (RVP PV, 2017). Digitální kompetence dětí předškolního věku a moderní technologie mohou pomoci dítěti lépe řešit problém (kompetence $\mathrm{k}$ řešení problému), učit se získávat poznatky a porozumět jim, postupovat podle instrukcí a uplatňovat zkušenost (kompetence $\mathrm{k}$ učení). $\mathrm{Na}$ Slovensku se práce $\mathrm{s}$ dětmi v mateřských školách orientovala na splnění cílů Programu výchovy a vzdělávání. Ten nepřikládal digitálním technologiím výraznou pozornost. Nový kurikulární dokument ISCED (ŠPÚ, 2009) nabádá učitele k využívání ICT. V britském kurikulu se objevuje poznávání každodenních technologií prostřednictvím ovládání programovatelné hračky. Pozornost digitálním kompetencím dětí předškolního věku věnuje i australské kurikulum (Connel et al., 2006).

\section{Výzkumný vzorek}

Anonymní nestandardizovaný dotazník vlastní konstrukce byl připraven speciálně pro učitele mateřských škol a distribuován $\mathrm{v}$ tišsěné podobě $\mathrm{v}$ rámci výše zmíněného projektu. Učitelům MŠ na realizovaných workshopech bylo předáno 60 dotazníků v papírové podobě, jejich návratnost byla $100 \%$, nebot' byly předány fyzicky. Výsledky tedy nezobecňujeme na prostředí celé ČR, ale týkají se pouze těchto sledovaných škol ve třech regionech České republiky.

Respondenty v rámci realizovaného výzkumného šetření byli učitelé mateřských škol na území tř́ krajů České republiky - Jihočeského kraje, Plzeňského kraje a kraje Praha. Všichni respondenti byli představováni ženami, což odpovídá typickému zastoupení mezi pedagogy v MŠ v ČR. Věkové rozpětí vzorku bylo 19 - 60 let. Ve věku do 40 let bylo 38 respondentek (tj. $63 \%$ ) a ve věku na 41 let 22 respondentek (37\%). Nadpoloviční většinu dotázaných tvořily stř̌edoškolsky vzdělané učitelky ( $72 \%$ respondentek), dále pak učitelky s vysokoškolským (25 \%) či vyšším odborným vzděláním (3\%). Respondenti byli složeni $\mathrm{z}$ učitelek působících $\mathrm{v}$ městských mateřských školách. Některé učitelky (respondentky) byly současně ředitelkami MŠ.

\section{Prezentace výzkumných výsledků}

$Z$ počátku jsme se zaměřili na zjištění úrovně infrastruktury reálného vybavení ICT (ve smyslu počitač a multimediální aplikace, multifunkční zařízení) ve vybraných třech lokalitách ČR v rámci zmiňovaného projektu.

\subsection{ICT vybavenost mateřských škol}

\begin{tabular}{|l|c|c|c|}
\hline \multicolumn{1}{|c|}{ Typ ICT } & Praha kraj & Jihočeský kraj & Plzeňský kraj \\
\hline MultiBoard & 3 & 1 & 1 \\
\hline 3BOX & 2 & 1 & 1 \\
\hline Interaktivní tabule & 6 & 1 & 4 \\
\hline Robotické hračky & 2 & 0 & 1 \\
\hline Počítač & 18 & 12 & 15 \\
\hline Kopírovací stroj & 19 & 17 & 18 \\
\hline Digitální fotoaparát & 19 & 18 & 15 \\
\hline Kamera & 10 & 8 & 9 \\
\hline
\end{tabular}




\begin{tabular}{|l|c|c|c|} 
CD přehrávač & 20 & 19 & 19 \\
\hline DVD přehrávač & 12 & 10 & 12 \\
\hline LCD TV & 15 & 12 & 18 \\
\hline Tablet & 5 & 1 & 1 \\
\hline$\sum$ & 131 & 100 & 114 \\
\hline
\end{tabular}

Tabulka č. 1: Reálná vybavenost ICT v MŠ ve třech krajich ČR

Z výsledků je patrné, že většina mateřských škol v kraji Praha, Jihočeském kraji i Plzeňském kraji je vybavena multifunkčními zařízeními (kopírovacím strojem, digitálním fotoaparátem, kamerou, CD a DVD přehrávačem, LCD TV), zatímco počítač a multimediální aplikace (MultiBoard, 3BOX, interaktivní tabule, tablety, programovatelné a robotické hračky) jsou reálně ve vybavení zastoupeny méně. Podle výsledků dotazníku jsou nejlépe multimediálně vybaveny MŠ v Praze. Obnova multimédií většinou probíhá, podle vyjádření ředitelů MS̆, po 5 letech. Značné rozdíly existují v technickém vybavení mateřských škol i uvnitř každého kraje. Technicky lépe jsou vybaveny ty MŠ, které se zapojily do projektů OP VVV nebo získaly finanční prostředky $\mathrm{z}$ různých dotačních programů či sponzorských darů. $Z$ rozhovoru s řediteli a učiteli škol vyplynulo, že chybí finanční prostředky na zakoupení oblíbených 3BOXů a MultiBoardů, programovatelných a robotických hraček, které by zefektivnily výuku a přispěly ke společnému vzdělávání všech dětí.

Na implementaci ICT do edukace mateřských škol má vliv také osobní zaujetí, postoje a motivace učitelů MŠ. V současné době není klíčovou otázkou, zda ICT začleňovat do výuky či ne, ale jakým způsobem s nimi pracovat, jak je implementovat do metodických postupů. Výsledky některých českých výzkumů z posledních let ukazují, že ředitelé podporují implementaci ICT do vyučování jako jednu z významných priorit (Pol a kol. 2005; Zounek, 2006). Proto jsme se dále zaměřili na identifikaci možných překážek (př́čin) nedostatečné implementace ICT do edukace mateřských škol.

\subsection{Překážky a př́činy nedostatečné implementace ICT do edukačního procesu v mateřských školách}

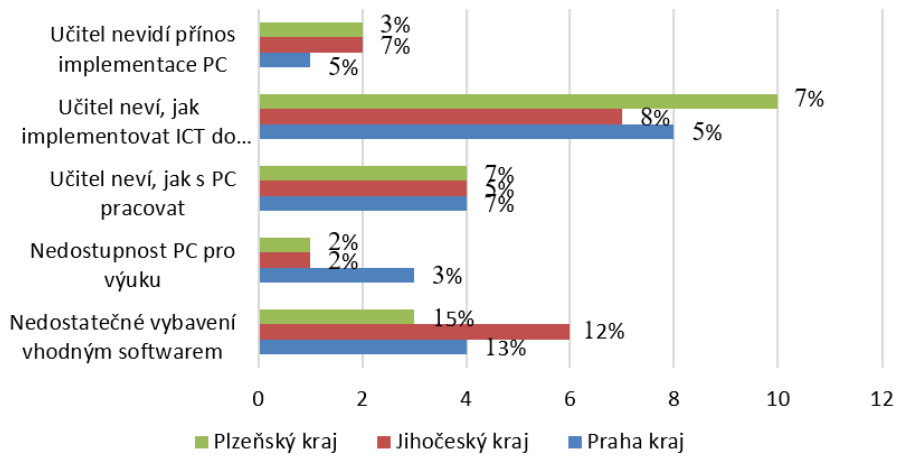

Graf č. 1: Přičiny nedostatečné implementace ICT do edukačního procesu MŠ 
Odpovědi na otázku poukazují na problémy s nedostatečným vybavením ICT a implementací ICT (Uhlířová, 2007). Učitelé MŠ (40 \%) vidí největší problém v nedostatečném kvalitním vybavení ICT (tj. PC $\mathrm{s}$ multimediálními aplikacemi), v neznalosti, jakými způsoby lze ICT do výuky metodicky implementovat (20 \%). Dalších $18 \%$ respondentů neví, jak s PC pracovat, $15 \%$ respondentů nevidí prínos implementace ICT a $7 \%$ respondentů z celkového počtu 60 dotázaných uvádí, že PC je nedostupný pro výuku.

Digitální gramotnost učitelů i vzdělávaných je základní prioritou Strategie digitálního vzdělávání do roku 2020. Jde o základní schopnost pracovat s počítačem a pohybovat se v prostředí on-line. Skalková uvádí (2002), že nestačí, aby učitelé měli k dispozici technologie a uměli s nimi zacházet, ale aby zvládali především didaktické situace spjaté s ICT. Z rozhovoru vyplynulo, že by většina učitelů MŠ přivítala vytvoření metodických materiálů o implementaci ICT do výuky MŠ v návaznosti na RVP PV. Zajímaly nás proto dále názory a postoje učitelů MŠ (pozitiva a negativa) na implementaci ICT do př̌edškolního vzdělávání, a to i v rámci společného vzdělávání.

\subsection{Spatřovaná pozitiva implementace ICT do výukového procesu MŠ}

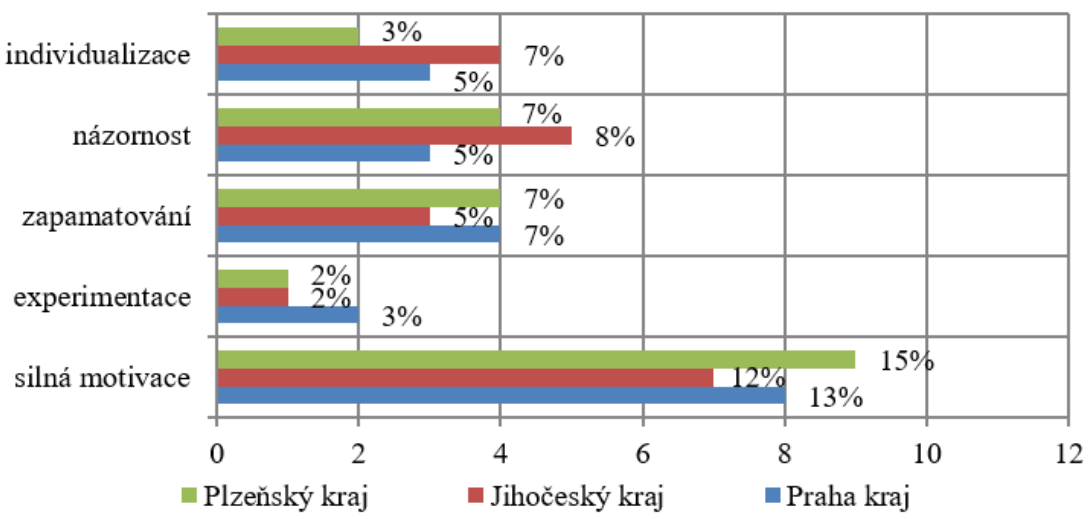

Graf č. 2: Identifikace názorů učitelů MŠ na pozitiva implementace ICT do edukace

Ve všech třech krajích ČR považují učitelé MŠ za největší pozitivum implementace ICT do edukace MŠ silnou motivaci (tj. $40 \%$ ze 60 respondentů). Dále oceňují názornost, tj. především vizualizaci učební látky (20\%), proces zapamatování (18\%) a ICT jako nástroj individualizace společného vzdělávání $(15 \%)$. Nejméně respondentů zvolilo odpověd” „experimentace“ (7 \%), nebot' se domnívá, že experimentace by měla být prováděna prakticky a reálně s konkrétními předměty. 


\subsection{Spatřovaná negativa implementace ICT do výukového procesu MŠ}

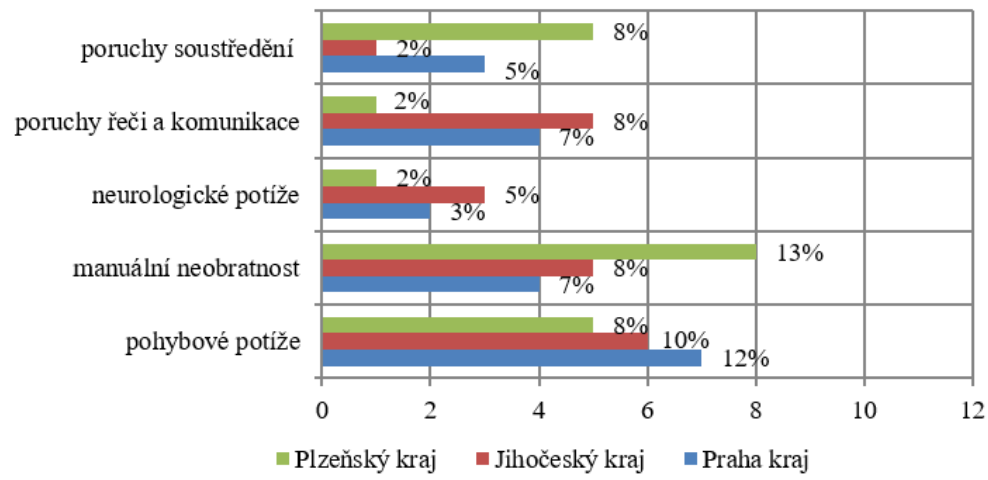

Graf č. 3: Identifikace názorů učitelů MŠ na negativa implementace ICT do edukace

Implementace ICT podle učitelů MŠ může mít také negativní dopady. Jednostranná pohybová zátěž může vést podle názoru $30 \%$ respondentů ke zdravotním pohybovým potížím a obezitě. $Z$ grafu je patrné, že učitelé MŠ v Plzeňském kraji vidí nejvíce negativní dopad na manuální obratnost dětí (13\%), celkový výsledek je pak zastoupen ve třech krajích $28 \%$ z 60 respondentů. Receptivní príijímání informací, nedostatečné produktivní slovní vyjadřování a poruchy řeči i aktivní komunikace vidí nejvíce učitelů MŠ v Jihočeském kraji (8\%), celkový výsledek je pak $17 \%$ z 60. Dále se učitelé vyslovují pro poruchy soustředění (15\%) a neurologické potíže dětí (10\%).

\section{Závěry a diskuse}

Studie navazuje na dříve publikované domácí i zahraniční práce (např. Hamplová, Dostál, 2012; Venezky, Davis 2002). Jde o prŕ́padovou studii, která vznikla z podnětu projektu OP VVV na podporu individualizace, tvořivosti a implementace ICT jako podpưrného prostředku edukace mateřských škol. Na základě provedeného výzkumného šetření poukazujeme na skutečnost, že samotná př́tomnost ICT ještě neznamená automaticky lepší výsledky procesu učení (Venezky, Davis 2002), ale vhodně využité ICT kreativním učitelem s digitálními kompetencemi dávají předpoklad úspěšné implementace moderních technologií do školní praxe. Studie si nečinila nárok na plně zobecnitelné závěry, pouze mapuje realitu ve třech krajích ČR (tj. vybavení mateřských škol ICT, digitální kompetence, názory a postoje učitelů MŠ) pro vytváření nových vzdělávacích strategií a implementaci ICT do preprimárního vzdělávání. To se může stát základem pro výzkumná šetření většího rozsahu.

Na základě triangulace docházíme k závěrům, že dle názoru dotazovaných učitelů mateřské školy ve všech třech sledovaných krajích ČR nedisponují kvalitním vybavením ICT, prričemž existují značné rozdíly ve vybavení jednotlivých mateřských škol i uvnitř krajů samotných. Přetrvává zájem o nákup 3BOXů, které jsou cenově nejlépe dostupné, 
multifunkční, variabilní, lehce přenosné a pro obsluhu nenáročné. Technicky lépe jsou vybaveny ty MŠ, které se zapojily do projektů OP VVV nebo získaly peníze z různých dotačních programů či sponzorských darů.

V souvislosti s tím se také nemohou adekvátně rozvíjet digitální kompetence učitelů MŠ i metodická připravenost začleňovat ICT do výuky. Na základě dotazníkového šetření a následně i rozhovoru jsme zjistili, že největším problémem, učitelů MŠ je to, že nevědí, jak s multimédii pracovat a jak je mají implementovat. Tento výzkum nezaznamenal, že by věk učitelů měl vliv na úroveň digitálních kompetencí a že by mladší učitelé (do 40 let), kteří se ve virtuálním světě sociálních sítí a digitalizace světa pohybují, vykazovali kvalitativně lepší digitální kompetence, než učitelé starší (nad 41 let). Nicméně tato proměnná jistě vstupuje také $\mathrm{v}$ potaz a může se stát předmětem dalšího zkoumání. $\mathrm{Na}$ základě rozhovorů s učiteli i řediteli MŠ jsme zjistili, že ačkoliv drtivá většina rozumí podstatě inkluze, nepovažuje ji v podmínkách C̆R za reálnou. ICT je ale významným podpůrným prostředkem v podmínkách nastupujícího trendu společného vzdělávání v MŠ.

Postoje a názory učitelů MŠ jsou často protichůdné. Mezi sledovanými učiteli převládá názor, že ICT je vhodným interaktivním nástrojem pro motivaci, názornost, vizualizaci učiva, pomáhá zapamatování a respektuje individuální vzdělávací potřeby všech dětí. Učitelé - nadšenci upozorňují na přednosti týmové práce a kompetence $\mathrm{k}$ řešení problému, učení a komunikativní kompetence. Učitelé-odpưrci konstatují, že každodenní kontakt s ICT má negativní dopady na zdravotní stav dětí, zejména na pohybové ústrojí, postavení páteře, ochablost svalů. Jednostranná zátěž podle nich vede $\mathrm{k}$ bolestem očí a hlavy, způsobuje nesoustředěnost, roztěkanost, manuální neobratnost. Spornými zůstávají názory na držení tužky - propisovače. Někteří učitelé poukazují také na to, že poznatky jsou prostřednictvím ICT předávány pouze receptivně, což vede $\mathrm{k}$ degradaci slovního projevu. Kritizují také, že děti tráví u PC mnoho času v době svého volna, a proto usilují o to, aby se v MŠ věnovaly spíše pracovním, výtvarným, hudebním, pohybovým a dramatickým (expresivním) činnostem a byl tak zajištěn rovnovážný a harmonický rozvoj osobnosti.

Na základě výzkumného šetření jsme dospěli k tzv. ,paradoxu technické vzdělanosti“ (Patterson, 2016; Dostál, Prachagool 2016). Ačkoliv jsme poslední tři desetiletí obklopeni stále více technikou a technickými „vymoženostmi“ je v mateřských školách stále problémem začlenit ICT do edukačního prostředí předškolního vzdělávání všech dětí.

\section{Literatura}

Bečvářová, I. (2016). Terapeutické aktivity při práci s dětmi se speciálními vzdělávacími potřebami. Prachatice: ASTERIA centrum vzdělávání, s.r.o.

Brdička, B. (2003). Role internetu ve vzdělávání. Kladno: AISIS.

Connell, P. et al. (2006). Early Years Curriculum Guidelines. Queensland Studies Authority.

Černochová, M. (2004). Didaktika zatím k ICT ve vzdělávání spíše mlčí - není to však také naší vinou? Aneb jsme ještě Komenského žáky? In Poškole, Sborník národni konference o počitačich ve škole 2004. Lázně Sedmihorky: Mezinárodní organizační výbor Poškole, Jednota školských informatiků.

Dostál, J. \& Prachagool, V. (2016). Technické vzdělávání na křižovatce - historie, současnost a perspektivy. Journal of Technology and Information Education, 8(2), 5-24. DOI: $10.5507 /$ jtie.2016.006. 
Easley D., \& O'Hara M. (2004). Informace a kapitálové náklady. The Journal of Finance, 59(4), 1553-1583.

Hamplová, M. \& Dostál, J. (2009). Výukový software a počítačové hry - nástroje moderního vzdělávání. Journal of Technology and Information Education, 1(1), 24-28. DOI: $10.5507 /$ jtie.2012.029.

Chráska, M. (2007). Metody pedagogického výzkumu. Základy kvantitativního výzkumu. Praha: Grada.

Institut pro veřejnou správu Praha. (2012). Slovník nejčastěji používaných pojmů ve veřejné správě. Praha, 2012 http://svs.institutpraha.cz

ISO/IEC/IEEE 24765: 2010. Systems and software engineering - Vocabulary, Ingénierie des systèmes et du logiciel - Vocabulaire. Geneva: ISO.

Patterson, G. (2016). What children need to know about tech. In World Economic Forum, http://www.weforum.org/agenda/2016/01/what-children-need-to-know-about-tech

Pol, M., Hloušková, L., Novotný, P. \& Zounek, J. (2005). Kultura školy. Př́spěvek $k$ výzkumu a rozvoji. Brno: Masarykova univerzita.

Rámcový vzdělávací program pro předškolní vzdělávání. (2017). http://www.msmt.cz/file/39793

Smolíková, K. et al. (2004). Rámcový vzdělávaci program pro předškolní vzdělávání. Praha: Výzkumný ústav pedagogický v Praze.

Skalková, J. (2002). Využívání médií jako didaktického prostředku v procesu školního vyučování. Pedagogika, 52(4), 445-462.

Spitzer, M. (2014). Digitálni demence. Brno: Host.

Spitzer, M. (2016). Kybernemoc. Brno: Host.

Strategie digitálního vzdělávání do roku 2020, MŠMT (2014). http://www.msmt.cz/uploads/DigiStrategie.pdf

Štátný pedagogický ústav (2009). Štátny vzdelávací program ISCED 0 - predprimárne vzdelavanie.

http://www.statpedu.sk/buxus/docs/kurikularnatransformacia/isced0predpr.pdf

Uhlířová, M. (2007). Typologie učitelů vzhledem k jejich postojům k využití počítače ve výuce primární matematiky. In Coufalová, J. (Ed.), Vyučováni matematice z pohledu kompetenci žáka a učitele 1. stupně základního vzdělávání. Plzeň: Západočeská univerzita. Venezky, R. L. \& Davis, C. (2002). Quo Vademus? The Transformation of Schooling in Networked World. OECD/CERI. http://www.oecd.org

Zounek, J. (2006). ICT v životě základnich škol. Praha: Triton. 